PRESCRIPTION FOR PROFIT 



\section{PRESCRIPTION FOR PROFIT}

How Doctors Defraud Medicaid

PAUL JESILOW, HENRY N. PONTELL, AND GILBERT GEIS 
The research presented here was funded by grants from the University of California, Irvine; Indiana University; and the National Institute of Justice, U.S. Department of Justice (\#82-1J-CX-0035).

University of California Press

Berkeley and Los Angeles, California

University of California Press, Ltd.

London, England

(C) 1993 by

The Regents of the University of California

Library of Congress Cataloging-in-Publication Data

Jesilow, Paul, 1950-

Prescription for profit : how doctors defraud Medicaid / Paul

Jesilow, Henry N. Pontell, and Gilbert Geis.

p. $\mathrm{cm}$.

Includes bibliographical references.

ISBN 0-520-07614-1 (cloth : alk. paper)

1. Medicaid fraud. 2. Physicians-Malpractice-United States.

I. Pontell, Henry N., 1950- . II. Geis, Gilbert. III. Title.

[DNLM: 1. Fraud. 2. Insurance Claim Reporting-United States.

3. Medicaid. 4. Physicians. W $\left.275 \mathrm{AA}_{1} \mathrm{~J}_{5 \mathrm{p}}\right]$

$\mathrm{RA}_{412.5 . U 6 J_{47}} 1993$

$364.1^{\prime} 6_{3}-\mathrm{dc} 20$

DNLM/DLC

for Library of Congress

$91-36944$

CIP

Printed in the United States of America

$\begin{array}{lllllllll}1 & 2 & 3 & 4 & 5 & 6 & 7 & 8 & 9\end{array}$

The paper used in this publication meets the minimum requirements of American National Standard for Information Sciences-Permanence of Paper for Printed Library Materials, ANSI Z $39.48-1984$. (2) 
For our families 
